\title{
Incidence of Thalassemia and Sickle Cell Disease in Chhattisgarh, Central India: Using Hardy-Weinberg Equations
}

\author{
Sapna Thakur*, Ravindra Sharma and Sharada Nandan Raw
}

National Institute of Technology, Raipur

"Corresponding author: Sapna Thakur, National Institute of Technology, Raipur, Mathematics, QN-1A, Street-11, Bhilai, Chhattisgarh 490001, India, Tel: +919425550550, E-mail: sapnarajput85@gmail.com

Received date: August 01, 2014, Accepted date: January 16, 2015, Published date: January 23, 2015

Copyright: ( 2015 Thakur S, et al. This is an open-access article distributed under the terms of the Creative Commons Attribution License, which permits unrestricted use, distribution, and reproduction in any medium, provided the original author and source are credited.

\begin{abstract}
Thalassemia and Sickle Cell Disease (SCD) both are genetic blood disorders occurring by destruction in red blood cells (RBCs). Every year about 300,000 infants worldwide are born with Thalassemia syndrome (30 per cents) and sickle cell anaemia (70 per cents. Globally, the percentage of carriers of Thalassemia is greater than that of carriers of SCA, but because of the high frequency of the sickle cell gene in certain regions the number of affected births is higher than with Thalassemia. Due to a large population, and same blood, marriage in many communities, there is always a high chance of genetic disorders in Chhattisgarh which is one of the growing states of India. The incidence of genetic blood diseases in Chhattisgarh is considered high. According to the screened population, it is observed that the prevalence of SCD was $2.1 \%$, sickle cell trait was $10 \%$ among different tribes. Also Thalassemia gene is prevalent in different Here we are describing the challenges, including lack of knowledge about genetic disease and less facility faced by parents in the Chhattisgarh his children affected by Thalassemia and SCD. We use Hardy-Weinberg equilibrium (HWE), a genetic approach for the prediction of allelic frequencies of SCD and Thalassemia. The aim of this study is to generate carrier frequencies of both the disease using HWE and accepting a number of resources which are useful for the eradication of SCD and Thalassemia from the affected population group.
\end{abstract}

Keywords: Genetic disease; Sickle cell anemia; Chhattisgarh; HardyWeinberg Equation (HWE); Thalassemia

\section{Introduction}

This research article work is about the present scenario of sickle cell anemia and Thalassemia in Chhattisgarh. The state Chhattisgarh came into existence on 1st November 2001 is situated in between the states of Madhya Pradesh and Orissa in the Central-East part of India which. It borders with the state of Jharkhand in the North and, Andhra Pradesh and Maharashtra states in the South. There are about 30 scheduled tribes in Chhattisgarh. The tribal population contributes about $32.46 \%$ of the total population of the Chhattisgarh, which means that every 3 rd person of the state is a tribe. The forest reserve comprises $12 \%$ of the forests of India and covers $44 \%$ of the total area of the state. The state is known for the cultivation of rice and is known as the rice bowl of India. It has rich biodiversity and has been declared as the herbal state of India [1]. Last 10 years that means between 20012011, it is established as a one of the growing state of India Chhattisgarh came into existence on 1st November 2001 it is situated in the central- east part of India. Madhya Pradesh and Orissa, both the states are neighbors of Chhattisgarh. Thalassemia and Sickle Cell Disease (SCD) both are genetic blood disorders occurring by destruction in red blood cells (RBCs). Every year about 300,000 infants worldwide are born with Thalassemia syndrome ( 30 per cents) and sickle cell anemia (70 per cents). Globally, the percentage of carriers of Thalassemia are greater than that of carriers of SCA, but because of the high frequency of the sickle cell gene in certain regions the number of affected births is higher than with Thalassemia [2]. Due to a large population, and same blood, marriage in many communities, there is always a high chance of genetic disorders in Chhattisgarh which is one of the growing states of India. The incidence of genetic blood diseases in Chhattisgarh is considered high. According to the screened population, it is observed that the prevalence of SCD was $2.1 \%$; sickle cell trait was $10 \%$ among different tribes. Also Thalassemia gene is prevalent in different. Here we are describing the challenges, including lack of knowledge about genetic disease and less facility faced by parents in the Chhattisgarh his children affected by Thalassemia and SCD.

\section{Prevalence of Thalassemia and Sickle Cell Anemia}

There are three main classes of genetic disorders which are, Singlegene disorders that mean mutations in single genes often causing loss of function, Multi factorial conditions which is variants in genes interacting with the environment and causing alteration of function, the last one is Chromosomal disorders which causes chromosomal imbalance and alteration in gene dosage [3]. With a very large population and high birth rate, and consanguineous marriage favored in many communities, there is a high prevalence of genetic disorders in India. An estimated 495,000 infants with congenital malformations, 390,000 with G6PD deficiency, and 21,400 with Down syndrome, 9,000 with Thalassemia, 5,200 with sickle cell disease, and 9,760 with amino acid disorders are born each year. Due to lack of diagnostic, management and rehabilitation facilities, the burden of these disorders is greater in underdeveloped countries. Although genetic diseases receive little attention from the health services, research funding by the government has been liberal. Community control of common disorders like Thalassemia, Neural tube defects, Down syndrome and muscular dystrophies deserves high priority. Genetic services should be integrated into the primary health care and medical services [4]. On the basis of pre-marital screening Cyprus was the first country to 
introduce a successful prevention program, and the annual birth rate has decreased to less than 5 cases per year from an expected 70-80 [5].

\section{Hemoglobinopathies}

Hemoglobinopathies describes a family of inherited genetic blood disorders. Estimation shows that $7 \%$ of the world's populations are carriers of the genes that may cause these disorders of hemoglobin. Every year, near about 300,000-500,000 children are born with severe inherited disorders of hemoglobin (Thalassemia \& Hemoglobinopathies). Out of these, $80 \%$ of them are born in middleand low-income countries. About 50,000-100,000 children are born with Thalassemia disease (Beta-Thalassemia Major) die each year in middle- and low-income countries. A patient with severe form of disease (Beta-Thalassemia Major) requires lifelong treatment, including regular blood transfusions and continuous iron chelation (removing excess iron from the body). To keep alive 500,000 patients with Beta-Thalassemia major [6,7] at least 15 million blood donations are needed every year.

Thalassemia and Sickle cell disease are common genetic blood conditions around 5\% of the world's population carries trait genes for hemoglobin disorders, mainly, sickle-cell disease and Thalassemia (WHO). In India, the SC trait occurs commonly among the tribal peoples in central India (southeastern Gujarat, Maharashtra, Madhya Pradesh, Chhattisgarh, West Odessa) a little to the south of the country (northern Tamil Nadu and Kerala), and trait frequencies as high as $40 \%$ have been described in some groups [8]. Beta-Thalassemia major in a developing country poses a major threat to the health services. Lack of facilities and coordination to make the treatment difficult in a variety of ways. Availability of antenatal diagnosis is not readily available, bone marrow transplantation, is out of reach for most of the parents because of financial problems. The need for prevention of Thalassemia is obvious due to high frequency of the occurrence, the great expenses and difficulties in providing optimal treatment for patients and the innumerable fatalities from untreated Beta-Thalassemia. Prevention would not only cost effective, but it would also be a good health practice, as the ratio of treatment to prevention is $4: 1$, as shown in the study from Israel. It would help tremendously in reducing the burden of the disease for patients, families and the health services. In the developed Countries focus is towards the prevention of disease by detection of Thalassemia carrier and marriage counseling. The result is Thalassemia patient has decreased from 1: 250 live births in 1: 1000 live births.

\section{Distribution of Thalassemia in India}

Thalassemia is a group of inherited red blood cell disorders, or a collection of recessive genetic disorders characterized by a hemoglobin variant called hemoglobin a. Thalassemia major is at times used interchangeably with Cooley Anemia or Beta-Thalassemia. Thalassemia is present almost in every community. The general incidence of Thalassemia trait in India varies between 3 and 17\% [8]. According to $\mathrm{WHO} 3.3 \%$ is the average frequency of Thalassemia carriers in India In the Madhya Pradesh High prevalence of $\beta$ Thalassemia trait $(20.7 \%)$ is observed in this Worldwide, approximately 15 million people are estimated to suffer from thalassemia disorders. Reportedly, there are about 240 million carriers of $\beta$-Thalassemia worldwide, i.e. $1.5 \%$ of world population, and in India alone, the number are approximately 30 million with 505 in S. E. Asia. The burden of hemoglobinopathies in India is high with approximately 12,000 infants being born every year with a severe disorder. These numbers imply that every hour 1 child is born who will suffer with this genetic disorder. The carrier rate for $\beta$ Thalassemia varies from $1-17 \%$ in India with an average of $3.2 \%$. This means that on an average 1 in every 25 Indians is a carrier of Thalassemia. The distribution of the Thalassemia gene is not uniform in India and the prevalence is very high among certain communities such as Sindhis and Punjabis from Northern India, Bhanushalis, Kutchis, Lohanas from Gujarat, Mahars, Neobuddhists, Kolis and Agris from Maharashtra, and Gowdas and Lingayats from Karnataka etc. and certain tribes in the northern, western and eastern parts, with lower incidence in the southern tribes. There is a genetic, ethnic and regional diversity of the hemoglobin variants as well as of the genetic mutations in India [4]. Weatherall and Clegg, 1996, According To the world health organization the higher carrier frequency it is 3 to 17 per cent are found out between the Sindhi communities. Rakholia et al. [9] determines the frequencies of Thalassemia in Sindhi community which is very prevalent of different region of India such as Mumbai, Ulhasnagar, Gujarat and Maharashtra, and Wardha.

The present study was designed with the following aims and objectives in mind: i) To determine the pattern of spectrum of Thalassemia and Sickle cell disease in the state of Chhattisgarh, ii) Define the ethnic groups at high risk of Genetic diseases like Thalassemia, Sickle cell anemia in Chhattisgarh iii) Geographical distribution of hemoglobinopathies iv) To know the epidemiological aspects of cases of Thalassemia trait in different areas of Chhattisgarh, and v) Using Hardy-Weinberg equation to find out Thalassemia carrier frequency.

\section{Method Description}

In this section we use the following steps

To find out the genotype frequencies in the given screened population.

Calculate what the allele frequencies would be in one generation of random mating. Calculate the frequencies of the dominant and recessive alleles ( $\mathrm{p}$ and $\mathrm{q})$.

Using the observed allele frequencies, calculate the genotype frequencies, you would expect under HWE.

Using Punnet Square to compute the next generation frequencies for SCD and Thalassemia.

\section{The Hardy-Weinberg Principle}

Even after most of geneticists had accepted Mendel's laws, confusion exists regarding the maintenance of genetic variation in natural populations. Some opponents of the Mendelian view contended that dominant traits should increase and recessive traits should decrease in frequency, which is not what is observed in real populations. In a paper Hardy refuted such arguments that, along with an independently published paper by Weinberg laid the foundation for the field of population genetics [10]. The Hardy-Weinberg theorem characterizes the distributions of genotype frequencies in populations that are not evolving, and is thus the fundamental null model for population genetics.

The Hardy-Weinberg principle states that the genotype frequencies A2, 2Aa, and a2 will not change if the allele frequencies remain constant from generation to generation (they are in equilibrium).

Expressed as: $\mathrm{A}^{2}+2 \mathrm{Aa}+\mathrm{a}^{2}=1$ 
Citation: Thakur S, Sharma R, Raw SN (2015) Incidence of Thalassemia and Sickle Cell Disease in Chhattisgarh, Central India: Using Hardy-

Hardy-Weinberg equation for the general case: $\mathrm{p} 2+2 \mathrm{pq}+\mathrm{q} 2=1$ and $\mathrm{p}+\mathrm{q}=1$

Allelic frequencies

$\mathrm{p}=$ frequency of the dominant allele in the population

$\mathrm{q}=$ frequency of the recessive allele in the population

Genotypic frequencies

p2 = percentage of homozygous dominant individuals

$\mathrm{q} 2$ = percentage of homozygous recessive individuals

$2 \mathrm{pq}=$ percentage of heterozygous individuals

The genotype frequencies and allele frequencies are in equilibrium if the following assumptions of the Hardy-Weinberg principle are met:

There is no natural selection

Mating are at random, all individuals reproduce equally, all offspring survive

There is no appreciable rate of mutation.

There is no migration.

There has been no genetic drift.

\section{Screening of Sickle Cell Disorder in Chhattisgarh State}

Sickle Cell Anaemia is a genetic disorder in the tribal belt of Central and Southern India. In India, the sickle cell gene is distributed mainly in Madhya Pradesh, Chhattisgarh, Maharashtra, Orissa, Jharkhand, parts of Andhra Pradesh, Kerala, Karnataka and Tamil Nadu [11]. In Chhattisgarh, the SC gene is common in various districts such as Dantewada, Bastar, Kanker, Korba, Mahasumund, Rajnandgaon, Dhamtari, Kawardha, Bilaspur, Durg, Raipur and Jangjir- Champa etc. $[12,13]$.

According to the research conducted at Pt. Jawaharlal Nehru Medical College (JNMC), around 10\% of the state's population has prevalence of sickle cell anemia specific to this region. Therefore around 25 lakh are affected from the disorder [14]. The following data (Tables 1,2 and Figure 1) collected from Pt. Jawaharlal Nehru Medical College (JNMC), Raipur which is clearly represents the severity of sickle cell trait and Sickle cell anemia in various districts of Chhattisgarh:

\begin{tabular}{|c|c|c|c|c|c|}
\hline District & $\begin{array}{l}\text { Screened } \\
\text { population }\end{array}$ & HbAS & HbSS & $\begin{array}{l}\text { Total } \\
+ \text { +SS) }\end{array}$ & $\begin{array}{l}\text { Percenta } \\
\text { ge }\end{array}$ \\
\hline Raipur & 516,251 & 49749 & 1,346 & 51,095 & 9.89 \\
\hline Durg & 395,805 & 35,244 & 1,115 & 36359 & 9.18 \\
\hline Kawardha & 51,407 & 5,747 & 116 & 5863 & 11.40 \\
\hline $\begin{array}{l}\text { Mahasamun } \\
\text { d }\end{array}$ & 154,198 & 18,290 & 713 & 19003 & 12.32 \\
\hline Total & 1117661 & 109030 & 3290 & 112320 & 10.04 \\
\hline
\end{tabular}

Table 1: Prevalence of sickle cell disease in selected districts in urban Chhattisgarh, India.

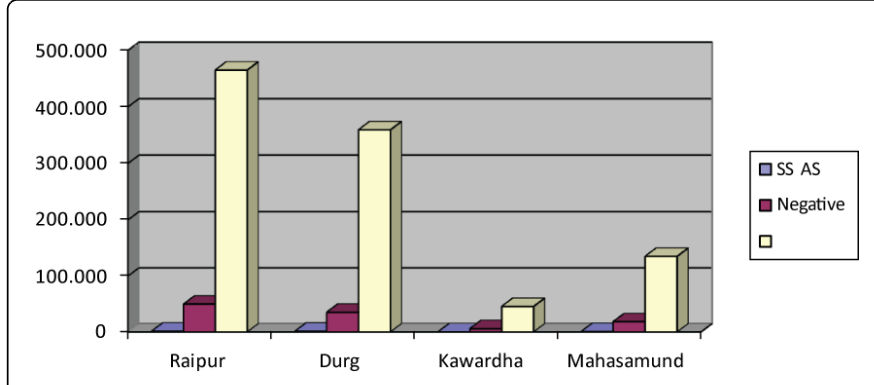

Figure 1: Column chart shows the frequencies generated by SS, AS and non-affected populations.

\begin{tabular}{|l|l|l|l|}
\hline Genotype & Expected(E) & Observed(O) & $\begin{array}{l}\text { Expected } \\
\text { frequency under H-W }\end{array}$ \\
\hline $\begin{array}{l}\text { Common } \\
\text { homozygotes (AA) }\end{array}$ & 1005040.65 & 1005341 & $89.92 \%\left(\mathrm{p}^{2}\right)$ \\
\hline Heterozygotes (Aa) & 109630.69 & 109030 & $9.81 \%(2 \mathrm{pq})$ \\
\hline $\begin{array}{l}\text { Rare homozygotes } \\
\text { (aa) }\end{array}$ & 2989.65 & 3290 & $0.27 \%\left(\mathrm{q}^{2}\right)$ \\
\hline
\end{tabular}

Table 2: For Chi-sq Hardy-Weinberg equilibrium test calculator using the link http://www.oege.org/software/hwe-mr-calc.shtml through which we can find out the difference between the expected value and the observed value.

$\mathrm{p}$ allele freq $=2119712(94.83 \%) ; \mathrm{q}$ allele freq $=115610(5.17 \%)$ and $\mathrm{P}$ value $=0$

\section{The Genetics of Thalassemia}

In a living organism a gene is a unit of heredity. It normally resides on a stretch of DNA. Genes hold the information to build and maintain an organism's cell and pass genetic traits to offspring [15]. The conditions are recessively inherited; hence, if two human carriers of the Thalassemia gene variant have a child, there is a 1:4 chance within every pregnancy that their child will have developed Thalassemia disease. The following Table 3, represents lists of possibilities of inheritance of Thalassemia.

\begin{tabular}{|l|l|l|l|}
\hline $\begin{array}{l}\text { Father } \\
\text { Mother }\end{array}$ & AA & a & a \\
\hline AA & All AA & $\begin{array}{l}1 / 2 \mathrm{AA} \\
1 / 2 \mathrm{Aa}\end{array}$ & All Aa \\
\hline $\mathrm{Aa}$ & $1 / 2 \mathrm{AA}$ & $1 / 4 \mathrm{AA}$ & $1 / 2 \mathrm{Aa}$ \\
& $1 / 2 \mathrm{Aa}$ & $\begin{array}{l}1 / 2 \mathrm{Aa} \\
1 / 4 \text { aa }\end{array}$ & $1 / 2$ aa \\
\hline Aa & All Aa & $1 / 2 \mathrm{AA}$ & All aa \\
& & $1 / 2$ aa & \\
\hline
\end{tabular}

Table 3: Probabilities of all genotypes given the parents' types.

Where gene a listed as Abnormal forms of hemoglobin gene, A listed as Normal form of Hemoglobin. During reproduction, three arrangements can form: two homozygous AA and a, and one 
Page 4 of 5

heterozygote Aa. In a simple manner, one can consider that each parent transmits one of their genes to each child, with the same probability. We can then compute the probabilities of each gene-type, given the parents' characteristics. For example, the children of two aparents have 1:2 chances to be a, one chance out of four to be AA, and $1: 4$ chance to be a.

To maintain an adequate supply of hemoglobin, Thalassemia of Hbaa type requires regular blood transfusions and sustains life. As a result of multiple transfusions, organs become severely overloaded with iron and a peculiar treatment is needed to manage this condition. Thalassemias can be cured by a successful bone-marrow transplant; however, this procedure is considerably expensive and not readily available in most settings. Recently, gene therapy has been successfully applied to a patient with Thalassemia. For confirmation of Thalassemia we advise parents to get a Complete Blood Count test (CBC), NESTRO test and the Hemoglobin Electrophoresis test done in case the doctor finds any abnormalities during. Though a bone marrow/stem cell transplant cures the disease permanently, people in India who are willing to donate are very less. They are skeptical that the donation would affect their health.

\begin{tabular}{|l|l|l|l|}
\hline District & $\begin{array}{l}\text { Screened } \\
\text { Population }\end{array}$ & Hub & Carrier Percentage \\
\hline Raipur & 1213 & 123 & 10.14 \\
\hline Durg & 1558 & 136 & 8.73 \\
\hline Tilda & 367 & 30 & 8.17 \\
\hline Bhatapara & 529 & 66 & 12.48 \\
\hline Raigarh & 276 & 32 & 11.59 \\
\hline Rajnandgav & 489 & 59 & 12.06 \\
\hline Chakarbhata & 324 & 53 & 16.36 \\
\hline Mungeli & 327 & 40 & 12.23 \\
\hline Total & 5083 & 539 & 10.60 \\
\hline
\end{tabular}

Table 4: Prevalence of Thalassemia trait in selected districts in urban Chhattisgarh [8], where sample size $\mathrm{N}=5083$.

\begin{tabular}{|l|l|l|l|}
\hline Genotype & Expected (E) & Observed (O) & H-W Frequency \\
\hline $\begin{array}{l}\text { Common } \\
\text { homozygotes (AA) }\end{array}$ & 4558.29 & 4544 & $89.68 \%\left(\mathrm{p}^{2}\right)$ \\
\hline Heterozygotes (Aa) & 510.42 & 539 & $10.04 \%(2 \mathrm{pq})$ \\
\hline $\begin{array}{l}\text { Rare homozygotes } \\
(\mathrm{aa})\end{array}$ & 14.29 & 0 & $0.28 \%\left(\mathrm{q}^{2}\right)$ \\
\hline
\end{tabular}

Table 5: Expected Genotype frequency using H-W principle. $\mathrm{p}$ allele freq=9627 (94.7\%); q allele freq=539 (5.3\%); P-value $=0.0001$

If we can compare the obtained results to previously generate a frequency of sickle cell traits, then we find the similar pattern of carriers in Chhattisgarh. Sickle cell trait and Thalassemia trait in the screened population are approximately 10 per cent (Table 4 ). Both the disease is associated with the blood effect, but they are different in severity since also variables as well as they diagnosed with similar treatment of both diseases are similar. Therefore, it is necessary to pay attention to both, but in Chhattisgarh if we check the results there are no any state level surveys conducted for Thalassemia. Of Chhattisgarh people don't know about Thalassemia (Table 5).

\begin{tabular}{|l|l|l|}
\hline Allele frequency & $\begin{array}{l}\text { Sickle cell disease } \\
(\%)\end{array}$ & $\begin{array}{l}\text { Thalassemia disease } \\
(\%)\end{array}$ \\
\hline$p$ & 94.83 & 94.7 \\
\hline$q$ & 5.17 & 5.3 \\
\hline Total & 100 & 100 \\
\hline
\end{tabular}

Table 6: Comparing the allele frequency of SCD and Thalassemia from the given sample.

\begin{tabular}{|l|l|l|l|l|}
\hline \multicolumn{2}{|l|}{ Gametes Sperm } & \multicolumn{2}{l|}{ Eggs } & $\begin{array}{l}\text { Allele frequencies next } \\
\text { generation }\end{array}$ \\
\hline \multicolumn{2}{|l|}{} & $0.95 \mathrm{~A}$ & $\mathbf{0 . 0 5} \mathrm{a}$ & \\
\hline$(p=0.95)$ & $0.95 \mathrm{~A}$ & $P^{2}=0.9025 \mathrm{AA}$ & $p q=0.048 \mathrm{Aa}$ & $P^{\prime}=0.9025+0.0475=0.95$ \\
\hline$(q=0.05)$ & $0.05 \mathrm{a}$ & $p q=0.048 \mathrm{Aa}$ & $q^{2}=0.0025$ aa & $Q^{\prime}=0.0025+0.0475=0.05$ \\
\hline
\end{tabular}

Table 7: One generation of random mating (using a Punnet square for the approximate values of SCD and Thalassemia) Assuming $\mathrm{p}=0.95$ and $\mathrm{q}=0.05$ for both SCD and Thalassemia.

since $\mathrm{P}^{\prime}=0.95$ and $\mathrm{Q}^{\prime}=0.05$

Therefore $\mathrm{P}^{\prime}=\mathrm{p}$ and $\mathrm{Q}^{\prime}=\mathrm{q}$

According to Tables 6 and 7, for both the disease the approximate frequencies for $\mathrm{p}$ and $\mathrm{q}$ are 0.95 and 0.05 respectively. Therefore, for both the diseases the probability of an A sperm meeting an A egg is $0.95 \times 0.95=0.9025$. The probability of an A sperm meeting an A egg is $0.95 \times 0.05=0.0475$. The probability of a sperm meeting an egg is 0.05 $\times 0.05=0.0025$. Next Then the calculation for generating the frequency of next generation, we use the Punnet square.

\section{Discussion}

We have seen the two generations frequencies which are same. There is a need of exact data to predict the actual rate of SCD and Thalassemic birth rate in Chhattisgarh. In Chhattisgarh government has set up the Thalassemia Institute, a dedicated Centre for treatment, research and counseling and training for Thalassemia disease. Also, various works are started to control the disease that is implementing the project and spreading awareness. Whereas, Sickle cell disease is less severe but there is need of actions to be taken for its prevention. Therefore, the requirement is of the strong strategy for reducing the burden of Thalassemia disorders is to complement disease management with prevention programmers. Inexpensive and reliable blood tests can identify couples at risk for having affected children. This screening is especially opportune before marriage or pregnancy, enabling couples to discuss the health of their family. Genetic counseling informs trait carriers of risks that the condition may be passed along to their children, the treatment needed, if affected by a hemoglobin disorder, and the possible options for the couple. Prenatal screening of genetic diseases raises a specific legal, ethical and social issue that requires our attention. The frequency of beta-Thalassemia trait has variously been reported from $<1 \%$ to $17 \%$ and an average of $3.3 \%$ [16]. Most of these studies have been carried out in small 
Page 5 of 5

population groups. Population groups with higher gene frequencies require screening programs and facilities for antenatal diagnosis as well as increased awareness and education programs to control the birth of Thalassemia major children.

Television, Newspaper, Radio etc. is playing an important role in the elimination of Genetic disease (GD) as Thalassemia and Sickle cell anemia in community of Chhattisgarh. Therefore spreading general awareness among the higher risk community is necessary. This is not only the responsibility of foundation and government to control the disease. But it is also the responsibility of every carrier and, especially, marriage women to visit the doctors regularly during pregnancy. Necessary medicines, blood and disposable injections should be provided in the Basic Health Units, Number of centers and free dispensaries should be increased. Government should spend more money to provide cheap or free treatment of disease in the population. Cost of patient's is living in rural areas, where an easy access to the divisional head quarter hospitals is not possible every time. So it is suggested that there should be a standard children's hospital in every subdivision. So that blood and other medicines will be easily available to the peoples of this area. Because of lack of awareness data collection related to rural and urban population is the biggest problem, which is faced by the researchers in Chhattisgarh, India?

Therefore a blood test should be conducted for couples before planning to start a family. So this will be aware of the possible genetic disease that their children may acquire. Genetic counseling will then be able to advise and present the options for the couple to decide on the family they want. Prenatal diagnosis can also able to detect any deformities or genetic disease of the child. Therefore, knowing that the child has Thalassemia major genes before it is born will help decrease the cases in Chhattisgarh.

\section{Conclusion}

Prevalence of sickle cell disease and Thalassemia trait is sparingly alarming stage in Chhattisgarh. Then the researcher determined that a great need exists for more research and education on this disease, especially for more research studies that examine Thalassemia awareness among various community populations in Chhattisgarh. The scarcity of Thalassemia research shows how our society fails to view sickle cell disease as a serious illness. Currently, our society's attention is on no inherited blood disorders, for example, HIV/AIDS, hypertension, and cancer. Without awareness and adequate funding, Thalassemia disease will continue to be a silent killer for young men and women around the world. The health burden related to Thalassemia and Sickle cell anemia is effectively reduced through management and prevention programs. Countries like Cyprus could achieve such status where large scale population carrier screening programs involving education and premarital counseling were also effectively employed besides prenatal diagnosis. In Chhattisgarh, there is an urgent need to initiate large scale population carrier screening of high risk communities along with proper education and spread of awareness.

\section{Acknowledgment}

The authors are thankful to Dr. P. K. Patra (PJNM) for their cooperation and support. Also Thanks to Thalassemia Welfare Society working for Thalassemia Awareness programs. Special thanks to General secretary Mr. Pramod Puri of Thalassemia welfare society, Bhilai for providing different data related to thalassemia and Sickle cell anemia.

\section{References}

1. Serjeant GR (2013) The natural history of sickle cell disease. Cold Spring Harb Perspect Med 3: a011783.

2. (2008) Human Genome Project Information (n.d.). Gene testing.

3. McConkie-Rosell A, Spiridigliozzi GA, Rounds K, Dawson DV, Sullivan JA, et al. (1999) Parental attitudes regarding carrier testing in children at risk for fragile X syndrome. Am J Med Genet 82: 206-211.

4. Madan N, Sharma S, Sood SK, Colah R, Bhatia HM (2010) Frequency of $\beta$-Thalassemia trait and other hemoglobinopathies in northern and western India. Indian J Hum Genet 16: 16-25.

5. Borry P, Goffin T, Nys H, Dierickx K (2007) Attitudes regarding carrier testing in incompetent children: a survey of European clinical geneticists. Eur J Hum Genet 15: 1211-1217.

6. Andrews C (2010) The Hardy-Weinberg Principle. Nature Education Knowledge 3: 65.

7. Edwards AW (2008) G. H. Hardy (1908) and Hardy-Weinberg equilibrium. Genetics 179: 1143-1150.

8. Thakur S, Sharma R (2013) Prevention Measures for Thalassemia in Chhattisgarh, India: With the help of mathematical models. American Journal of Mathematics and Mathematical Sciences 2: 193-200.

9. Telfer P, Coen PG, Christou S, Hadjigavriel M, Kolnakou A, et al. (2006) Survival of medically treated thalassemia patients in Cyprus. Trends and risk factors over the period 1980-2004. Haematologica 91: 1187-1192.

10. Regional Collaborating Office of Thalassemia International Federation (RCOTIF).

11. Fabryova V, Babusik P, Laluhova-Striezencova Z, Drakulova M, Oslancova M (2012) Nineteen Years Study of Beta-Thalassemia in Slovakia. Cent Eur J Public Health 20: 239-243.

12. http://timesofindia.indiatimes.com/city/raipur/Sickle-cell-anemiaprevalent-in-10-of- Chhattisgarh-population.

13. Urade BP (2012) Incidence of Sickle Cell Anemia and Thalassemia in Central India. Open Journal of Blood Diseases 2: 71-80.

14. Sickle Cell Institute Chhattisgarh (SCIC), Raipur.

15. Kaur M, Dangi CBS, Singh M, Singh H, Kapoor S (2013) Burden of Sickle Cell Diseases among tribes of India- a burning problem. Int Res J Pharm. App Sci 3: 60-80.

16. Patra PK, Panigrahi SK, Baneree G (2013 Epidemeological Profile of Sickle Cell Disease Prevention in Chhattisgarh, central India. Int J Pharm Bio Sci 4: 513-518. 